Article

\title{
Riding the Populist Web: Contextualizing the Five Star Movement (M5S) in Italy
}

\author{
Liza Lanzone ${ }^{1}$ and Dwayne Woods ${ }^{2, *}$ \\ ${ }^{1}$ Laboratoire ERMES, University of Nice Sophia-Antipolis, Nice 06050, France; E-Mail: lanzone.lisa@gmail.com \\ ${ }^{2}$ Department of Political Science, Purdue University, West Lafayette, IN 47907, USA; E-Mail: dwoods2@purdue.edu \\ * Corresponding author
}

Submitted: 12 February 2015 | In Revised Form: 7 May 2015 | Accepted: 11 May 2015 |

Published: 11 August 2015

\begin{abstract}
This article focuses on three mechanisms to explain the rise of populist movements across Europe. They are politicization of resentment, exploitation of social cleavages, and polarization of resentment and feelings of non-representation. We conceptualize populism as a strategic power game aiming to transform potential majorities into real ones by creating or reframing social cleavages. Our theoretical model is used to explain the rise of the Five Star Movement (M5S). Beppe Grillo's M5S gained notoriety on the national political scene in Italy just before the 2013 elections and succeeded in getting nearly 25 percent of the overall vote. Moreover, it was the only political force that was able to attract votes across the different regions in Italy, making it the country's only truly national party.
\end{abstract}

\section{Keywords}

corruption; crisis of representation; Five Star Movement; political caste; populism

\section{Issue}

This article is part of a regular issue of Politics and Governance, edited by Professor Andrej J. Zwitter (University of Groningen, The Netherlands) and Professor Amelia Hadfield (Canterbury Christ Church University, UK).

(C) 2015 by the authors; licensee Cogitatio (Lisbon, Portugal). This article is licensed under a Creative Commons Attribution 4.0 International License (CC BY).

\section{Introduction}

Beppe Grillo's Five Star Movement (M5S) surged onto the national political scene just before the 2013 parliamentary elections and succeeded in getting nearly 25 percent of the overall vote. Moreover, it was the only political movement that was able to attract votes across the different regions in Italy, making it the only national party in the country (Diamanti, 2013). It elected 163 deputies-109 to the lower Chamber of Deputies and 54 to the Senate. Even Forza Italia with its phenomenal rise in the 1994 elections did not produce similar results. In that election, Silvio Berlusconi's party reached $21 \%$ and did better in the northeast and south than in the center or northwest. In addition to the rapid breakthrough of M5S, another noteworthy element in that election was the level of voter volatility, one in ten voters remained undecided until the election and more than $40 \%$ of electors voted in a different way compared to the 2008 general elections (Bordignon \& Ceccarini, $2013 a$, p. 5). The nonparticipation level reached a record 26 percent (about 5 percentage points above previous elections). While the above descriptive facts are interesting in themselves, they do not provide any explanation that accounts for the movement's success in the 2013 elections (Diamanti, 2013).

In this article, we explain the rise of the Five Star Movement by providing a contextual analysis as to why Italy, more so than other Western European democracies, has been beset by diverse forms of populism such as the Northern League, Forza Italia and the Five Star Movement (Woods, 2014). Our analysis is based on primary and secondary data sources, a web-based survey of M5S adherents, and limited open-ended inter- 
views with M5S supporters. The overarching thesis of this article is that the rise and persistence of populism in Western European democracies is an indication of a crisis of representation (Albertazzi \& McDonnell, 2008; Albertazzi \& Mueller, 2013; Santoro, 2012; Taggart, 2002, 2004). A crisis of representation can arise from different factors-structural and/or conjunctural-, such as a change in generational loyalties, a drop in partisan identification, or an exogenous shock to the political system. In the case of Italy, the crisis was initially an internal one; however, external factors have played their part.

The postwar party system that took root in the early 1950s and lasted until the early 1990s underwent a gradual and then accelerated decline as its social, ideological, and institutional links to Italian citizens eroded (Kriesi, 2014). The crisis of the Italian First Republic led to what some deemed a transition to a so-called Second Republic. For many, the adoption of mixed electoral rules in the referendum in 1993 that moved Italy away from the previous proportional representation system and recast party competition into center-left and center-right blocs served as the strongest indication that a transition had occurred. Bull (2012), Bull and Rhodes (2009), and Newell (2009) argue, however, that the focus on the purported transition from a First to Second Republic has obfuscated the continuity and persistent problems with political representation in Italy. As Bull and Rhodes $(2009$, p. 6) state:

The equilibrium of Italy's post-war system was clearly "punctuated" by the political and economic upheavals of the early and mid-1990s. But what followed has been less of a "transition" to something new, and more of a post-crisis process of institutional (re-) stabilisation and negotiated change in which the 'new' (or at least substantial parts of it) looks remarkably similar to the "old".

We situate the rise of Five Star Movement within the broader context of the crisis of representation of the First and the so-called Second Republic.

This paper is organized into six parts. We start by framing the rise of Five Star Movement within an analytical and theoretical model that explains the rise of populist movement along three dimensions: politicization of resentment, exploitation of social cleavages, and the polarization of feelings of non-representation. Then, we focus on the crisis of representation that has characterized the Italian political system for quite some time. Next we lay out the populist discourse employed by M5S to politicize resentment. Followed by an analysis of the movement's reframing of social cleavages in Italy with a web-based ground up mobilization strategy. Finally, we provide an empirical snapshot of who supports Grillo's movement, concluding with a brief assessment of the contradictory aspects of the movement that could threaten its long-term durability.

\section{The Analytics of Populism and the Crisis of Representation}

As an analytical tool, populism has gotten somewhat of a bad reputation as an amorphous concept with little empirical traction. Ironically, much of this negative reputation comes from scholars who employ the concept. The frequently uttered cri de coeur from them regarding populism is that it is a vague concept that lacks a coherent definitional basis. As Ernesto Laclau (1977, p. 143) emphatically put it, "few [terms] have been defined with less precision. We know intuitively to what we are referring when we call a movement or an ideology populist, but we have the greatest difficulty in translating the intuition into concepts." Nearly everyone employing the concept begins with this type of observation: that the concept lacks a clear theoretical frame and that its use causes confusion due to the absence of a settled and shared definition. Then, most studies of populism proceed with the assertion that despite its lack of settled and shared definitional basis and methodology, there is a broad consensus in the literature that the concept has, at least, three core components that can be viewed as common denominators that function as a relatively coherent conceptual framework that suffices as the basis for empirical assessments of populism (Mudde, 2004).

Jagers and Walgrave (2007, p. 322) make a good case that "populism always refers to the people and justifies its actions by appealing to and identifying with the people; it is rooted in anti-elite feelings; and it considers the people as a monolithic group without internal differences except for some very specific categories who are subject to an exclusion strategy". These three core elements anchor populism analytically and empirically. It is our view that Jagers and Walgrave are correct and thus those in the extant literature who claim that populism lacks a settled and shared definition are wrong. Essentially, what many authors in the literature on populism are doing is confusing the conflicting imperatives of the concept with its analytical utility.

All concepts have conflicting imperatives, defined as "interdependent but contradictory goals, priorities, or motivations that underline many social and political relationships" (Gould, 1999, p. 439). As an analytical tool however, populism has a coherent definitional basis. What it lacks is a neatly articulated theoretical identity. In other words, populism is not a theory in terms of having a system of consistent assumptions; however, it is a robust concept that can be fitted into different theoretical frameworks. In this respect, the conflicting imperatives of populism have contributed to its ability to capture within its conceptual net historical, cultural, and context-specific forms of populism. The analytical utility of populism has been particularly pertinent in understanding the diverse developments of populism in many Western European democracies. Pappas (2012) 
provides a theoretical model that encapsulates the three core analytical elements of populism and helps in explaining the rise and, in some cases, persistence of populist social and political movements. He theorizes that "populism obtains when a certain political entrepreneur is able to polarize politics by creating a cleavage based on the interaction between 'the people' versus some establishment, thus forging a mass political movement" (Pappas, 2012, p. 8). He adds that populism is best analyzed "as a strategic power game aiming to transform potential majorities into real ones by creating novel social cleavages". Pappas (2012, pp. 8-9) specifies three mechanisms that are sufficient conditions in understanding the causal link between crises of representation and populism. The first is politicization of resentment:

When resentment is high, established parties, whether in government or in opposition, are more likely to try containing it lest it upset existing political alignment patterns. This is not however true for populist parties, which thrive precisely on politicizing resentment and the sense of victimhood that accompanies it.

The second mechanism is the exploitation of social or political cleavages. It is understood as a key step in the way that populist leaders exploit latent or salient feelings of non-representation. Populist leaders and the rhetoric they use are able to do this by identifying a political or social divide between "the people" and the people's enemies. Failure of "true" or "real" representation is presented as the fault of the status quo. This is reflected in a common assertion that populism builds upon, a "we versus them," a Schmittian divide that splits societies into two broad social categories, "the people" and some "establishment". The third mechanism is polarization of resentment and feelings of nonrepresentation. Pappas (2012, p. 9) concludes that this mechanism is essential for populism to emerge in the form of a party or mass movement since "it involves pitting the disenchanted and resentful people against the privileged establishment in an antagonism of such a great intensity that it may threaten to tear society apart. When polarized, societies tend to cluster around opposing poles; as the majority of the people cleave to one pole or the other, the middle ground of politics gets lost and the median voter becomes a rare occurrence".

\section{Crisis of Representation: The Italian Case}

Starting in the 1980s, Western European democracies have seen the emergence of populist movements and parties along with the rise of anti-status quo discourse. While populism has spread across Europe, the populist phenomenon has gained traction in some countries more than others. This is particularly the case in Italy
(Ignazi, 1996; Tarchi, 2008; Woods, 1992, 1995, 2010, 2014). With the collapse of the Christian Democratic and Italian Communist parties' hegemony in the early 1990s, the Italian party and political system underwent a significant transformation (Mannheimer, 1991, 1993). An insurgent regional populist movement, the Lombardy League, later known as the Northern League and one of Italy's riches businessman, Silvio Berlusconi, emerged as pivotal populist players on the Italian political landscape in the context of the implosion of the two main pillars of the postwar Italian political system. The collapse of the Berlin Wall and the ending of communism in Eastern Europe had a direct impact on the Italian Communist Party, forcing it to transform itself into a more typical social democratic political and ideological formation. Then, in 1992, the anticorruption operation Mani Pulite (clean hands), sometimes referred to as Tangentopoli, spearheaded by judges in Milan put the Christian Democrats and the Italian Socialist Party under enormous pressure (Lazar, 2013, p. 320). While the immediate cause of the collapse of the postwar party system was these exogenous shocks, the endogenous decline within the context of political representation of the two dominant pillars of the postwar system, the Christian Democrats and the Italian Communist Party, had become manifest by the late 1980s.

Shin and Agnew (2008, p. 68) provide data on the secular decline that the major parties faced before the external shock of the corruption scandals to the party system. Their data illustrate that between 1976 and 1992 there had already been significant erosion in electoral support for the largest parties relative to the rise in popular support for various "protest" parties such as the League and the Greens and a revived PSI. In 1976 fully 73.1 percent of the vote for the Chamber of Deputies went to DC and the PCl; but by 1987 this had fallen to 60.9 percent. And in 1992 DC and the two main heirs to the PCI (PDS and Refounded Communists) accounted for only 51.4 percent of the vote for the Chamber. So, if Tangentopoli was the defining moment for the final demise of the old system, the two largest parties had already begun losing their electoral centrality long before. The end of the cold war, the failure of DC to respond adequately to the demands of its historic constituency of small businesses in the Northeast, and the relative breakdown of the Communist and Catholic political sub-cultures (particularly the Catholic one) all seem to have played some role in this loss of centrality.

In the institutional breach, two different forms of populism emerged. Berlusconi created, literally overnight, a political party to take advantage of the vacuum left on the center-right with the collapse in 1993 of the long dominant Christian Democratic Party (DC), and Umberto Bossi's insurgent regionalist movement took advantage of the crisis of the institutional status quo to propose a new form of political and social representation. More recently, the Five Star Movement has seized 
on the crisis of representation afflicting the electoral and party systems dominated by Berlusconi, the Northern League, and the De Democratic Party (PD) to call for a radical overhaul of the political system. Grillo's populism is calling for a less elite and party-dominated form of political representation. It relies heavily on social media and other nontraditional types of direct participation to bring about what it claims are more direct and participatory forms of democratic representation.

Mair (2002) feared that the rise of populism indicated a systemic crisis of political representation across Western Europe. He saw the decline of party systems and increased voter volatility as manifestations of the crisis. The decline of political parties entailed the loss of an important intermediary institution between citizens and the state. Kriesi $(2014$, p. 364$)$ provides a summary of Mair's view on the function of parties in a democratic system:

Arguably, political parties are the most important organizations linking voters and their representatives in established democracies. But parties have a double function: they not only link civil society to the polity, they also organize and give coherence to the institutions of government. As Peter Mair...observes, their unique contribution to the development of modern democracy was that they combined these two crucial roles (representation and government) into one.

If parties lose their representative function, Mair argued that this "opened the door for populist protest" (Kriesi, 2014, p. 361). Kriesi and Pappas (2015, p. 18) identified contrasting responses to the loss of representative functions by parties in Europe:

The populist surge has been particularly strong in Southern and Central-Eastern Europe. The two types of surges show, however, different patterns: while the more recent wave of CEE populism and anti-establishment mobilization more generally is partly (but certainly not exclusively) related to the emergence of "purifier" parties promising better and scandal-free governance, Southern European populism is generally highly polarizing, often antisystemic, and thriving on the left as well as on the right of the political spectrum.

All three of the mechanisms identified by Pappas (2012) are evident in the rise of the Five Star Movement.

\section{The Politicization of Resentment: The Rise of Civic Populism}

The M5S was born in 2005 as local civic lists and was officially founded in 2009. At the outset, the movement began as a blog by the Italian comedian, Beppe Grillo. Immediately, the blog gathered a large following. Grillo used his blog to comment on various political and social issues in Italy and globally. For example, the blog became a focal point for those in Italy who opposed the Iraq and Berlusconi's support of President Bush. Somewhat like a "catch-all" phenomenon, Grillo's blog had something for everyone. The most salient theme that he developed was his attack on the Italian political class, referred to as the "caste" (Rizzo \& Stella, 2007). He highlighted the many privileges that elected officials in Italy benefited from and accused them of collusion and corruption. Using the internet as a focal point to galvanize an angry public, Grillo called for a day of action-V-day-to clean up a corrupt parliament (Casaleggio \& Grillo, 2011).

Borrowing from the online activism tradition in the United States, Grillo called for the creation throughout Italy of local civic groups. As Mosca (2014, p. 41) points out, "initially, the blog represented an important hub for his fans all over the country. In July 2005, he suggested that his supporters create local groups using the Meetup platform. As explicitly recognized by Casaleggio, this choice was inspired by the American group MoveOn. Civic lists mushroomed. In some instances, they were newly created local groups and in others they were already existent groups that had been formed around local issues that joined the network (Lanzone, 2014). The objective of V-day of action was to crystallize the latent resentment against what Grillo identified as a corrupt political caste. The different civic groups were tasked with mobilizing supporters to protest on 7 June 2007 in town centers throughout Italy. The success of V-day led to a V-day two the following year with Grillo collecting signatures for a referendum to abrogate the Gasparri law on the media that he claimed limited free speech. The civic lists entered the electoral arena in $\mathbf{2 0 0 7}$ under the banner of "friends of Bepe Grillo". Grillo invited these groups to aggregate themselves into a common movement under the symbol of the Five Star Movement. The five stars reflected the "catch-all" element of Grillo's blog and protests. The stars represented one for clean energy, water, internet connectivity, garbage collection and social services.

The Five Star Movement style of populism tied resentment over local environmental and social services issues to a larger national theme of a nonrepresentative political caste (Bordignon \& Ceccarini, 2012). Typical of a populist strategy of communication, the M5S used resentment over different issues, in most cases local or regional, to crystallize the theme of "us" versus "them." In this respect, the M5S emerged as a constellation of local issues galvanized around a populist thematic of politics and political representation being about the real people. The movement's political slogans emphasize the sovereign people (Bordignon \& Ceccarini, 2013b). Grillo's movement benefited from ty- 
ing local issues to national themes. The success of this strategy was demonstrated with M5S unexpected success in the 2012 municipal elections followed a few months later with its triumph in regional elections in Sicily. In regards to the 2012 elections in Sicily, Grillo used the mix of online discussion and populist themes as way to support local M5S candidates despite little media coverage. He engaged in a variety of different publicity stunts to draw attention to himself and local issues.

As Bobba and McDonnell (2012, p. 4) point out:

The successful mixture of online and offline, Grillo and grassroots, was well in evidence during the October 2012 Sicilian regional election campaign. Having swam (the relatively short distance) across to the island from Calabria, Grillo proceeded to pack out piazzas across Sicily in support of local M5S candidates chosen from the meet-ups. As a result, the M5S candidate for the regional presidency Giovanni Cancelleri rose in just a few weeks from less than 5 per cent in the polls to take over 18 per cent (and third place) in the election.

The linking of local issues with a broader populist thematic is illustrated, for example, in the movement's clever campaign poster that said, "vote for you" (Figure 1).

Obviously, the objective was to mobilize the growing number of non-voters and those alienated from the mainstream parties. For obvious reasons, the politics of resentment focused on the "corrupt political caste". In his 2013 national election campaign that Grillo called the "Tsunami Tour", he invoked the metaphor of a wave washing away the corrupt Italian party system (Figure 2).

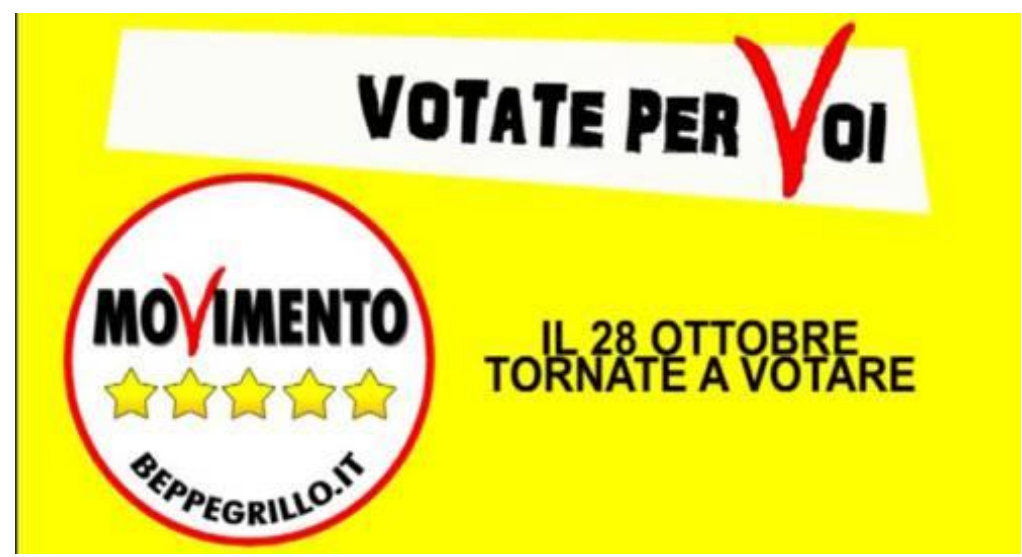

Figure 1. "Vote for You." 2012 Sicilian Regional Election Campaign. ${ }^{1}$

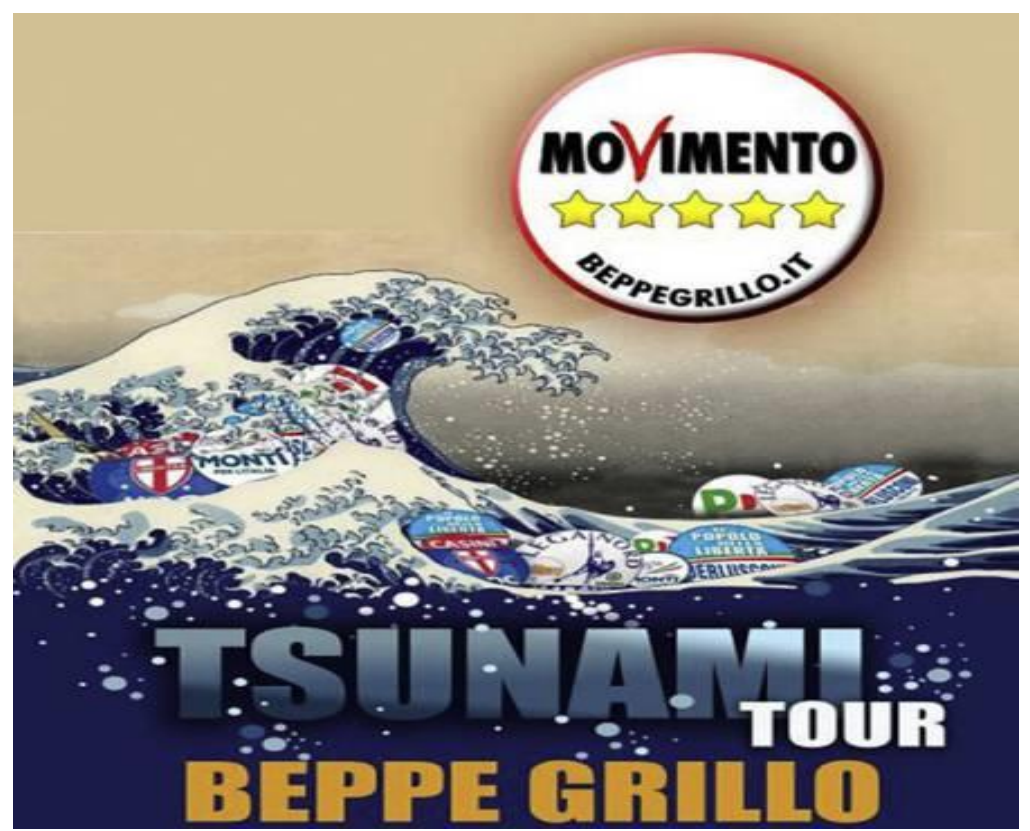

Figure 2. Tsunami Tour. 2013 General Election Campaign. ${ }^{2}$

\footnotetext{
${ }_{1}^{1}$ Posters are in the public domain and available on the movement's website: http://www.beppegrillo.it/europee/diffondi/

${ }^{2}$ http://www.beppegrillo.it/europee/diffondi/
} 
Essentially, M5S exploited the myriad of local and regional conflicts and controversies throughout the country and blamed their non-resolution on the political "caste" in power in Rome. A good illustration of how M5S exploited local issues is how they inserted themselves into the long simmering controversy over constructing a tunnel for a high-speed train between Turin and Lyon. It was a salient issue in Piedmont and had often resulted in acts of violence to prevent the project going forward. Grillo framed the project as proof of the collusion between the political "caste" in power and the Mafia, stating that:

They open the tunnel to the mafias! The International Treaty about Tav [the Turin- Lyon line] compromises to advantage the mafia structures. According to this international agreement, the contract work procedures about the Turin-Lyon's constructive projects will be overpowered to the French legislation, where is missing a specific rules against mafia organizations. (Five Star Movement's Senators, April 2014) ${ }^{3}$

Although the M5S movement vehemently rejects being classified as a political party or engaged in politics in any traditional fashion, much of its rapid success is due to its "catch-all" populist strategy. This "catch-all strategy" has allowed M5S movement to redefine old cleavages and articulate new ones.

Typically, populists present a transversal political ideology that transcends traditional dichotomies such as left and right and workers/owners. Populist movements arise principally to recreate a lost authenticity of the people. Grillo's movement is no different. Five Star Movement's rhetoric on cleavage issues reflects a sort of trans-ideological strategy and more specifically an "anti-political" focus (Diamanti, 2013, p. XV), aimed at appealing to electors from different political tendencies. The success of the Five Star Movement in the 2013 elections suggests that this strategy worked since the party succeeded in attracting support across Italy and the traditional left-right divide. Unlike the populism of the Northern League and Forza Italia whose electoral success and appeal was concentrated in certain regions and appealed to center-right voters who had previously supported the Christian Democrats, the Five Star Movement largely overcame the normal left/right or north/south divisions. Distrust in traditional cleavages was demonstrated by Five Star Movement's supporters in a web-survey realized in 2013 in which they indicated a strong interest in politics -67 percent declaring that they were interested in political issues-but a rejection

${ }^{3}$ Full text is available at this link:

http://www.beppegrillo.it/movimento/parlamento/2014/04/t av-aprono-il-tunnel-alle-mafie.html of the traditional left-right divide. ${ }^{4}$

\section{Redefining Cleavages through Populist Rhetoric}

With a "catch-all" thematic, the Five Star Movement has been able to put "old wine into new bottles" (Bordignon \& Ceccarini, 2013b). Unlike the Northern League that created ex nihilo a quasi ethno-regional cleavage out of northern resentment over taxes and state transfers to the poorer south or Berlusconi's repackaging a traditional anti-communist theme, the Five Star Movement simply aggregated local issues into a national grievance framework. In doing so, it has been able to present itself as representative of the Italian people irrespective of region, class, past ideological affiliation. In this respect, it has emerged as the most successful transideological party on the Italian political scene. However, the aggregation of disparate local and regional issues threatens any attempt to fashion a more coherent ideological identity. This accounts for why Grillo and other M5S leaders are constantly on the attack against the "other", i.e., corrupt and conniving politicians, austerity imposing external forces, and unscrupulous capitalists.

All populist movements emphasize how an "other" threatens some essential quality of the people: be it cosmopolitan capitalism, finance elites, corrupt politicians or foreign forces. Grillo's rhetoric is infused with the populist thematic of the real people fighting against an entrenched and corrupt elite. This recurrent antielitist refrain is employed to highlight the purported virtues of the people as the source of political legitimacy (Meny \& Surel, 2002). Also, the "us" versus "them" thematic of populist ideology and rhetoric is forever present. In fact, the entire civic structure of the Five Star Movement is premised on the idea that it allows for a form of direct democracy that traditional political parties are against. As Bordignon and Ceccarini (2013b, p. 435) put it:

The concept of political representation proposed by the M5S should be understood, then, as representativeness. The leader underlines this whenever "his" candidates run for elections: the resemblance between the public square and the MoVimento is explicitly presented as an alternative to the distance between citizens and politics: "They are all people like you. They are your mirror, democracy back to

\footnotetext{
${ }^{4}$ The survey was carried out in 2013 by one of the coauthors (between the 27 of February and the 19 of March), with the CAWI method (Computer Assisted Web Interviewing), on a sample of 628 people. The questionnaire consisted of 34 questions. The web survey was hosted by the online platform "Survey Monkey", thanks to the collaboration of the Five Star Movement's local groups' referents, which undertook to forward the link to the national members. Political interest was measured on a 1-10 scale. The values cited in this paragraph consider the 8-10 preferences.
} 
front"...."They are your people, taken from here and placed there....Surveyors, an engineer, a student, a lawyer, a drug dealer to keep our morale up a bit there are all sorts"...Politics, for Grillo, is a simple matter: the lack of professionalism and the inexperience of political employees are regarded as values, offering a guarantee that these people are extraneous to the circuits of power.

Distrust of elites is an old theme in Italian politics. Even before the collapse of the traditional post-World War II parties in the 1990s, Italians conveyed in opinion surveys a growing distrust of parties and their governing class. Grillo reanimated this distrust in claiming that the parties that had replaced First Republic parties were no different. Little had really changed. He attacked parties across the political spectrum. Grillo's leitmotif is that political parties are a kind of organized racket whose only interest in elections is to gain access to the privileges and perks given to elected officials in Italy. His attacks are stoked by widespread indignation about the political ruling class, now commonly referred as the "caste" (Rizzo \& Stella, 2007).

In various rallies and online discussion Grillo attacked the Italian political class as a corrupt and self-serving elite who had done little for real Italians. He argued that the major interest of career politicians was to gain parliamentary immunity, generous retirement benefits and expense accounts. Besides these rents, they cared little about policy or representation. Grillo contrasted the supposed spontaneous civic aspects of the Five Star Movement with the corrupt party system. He asserted that (cited in Bordignon \& Ceccarini, 2013b, p. 435):

The political parties are dead. Citizens need to detach themselves from the dead while they are still in time"(PC19, 2009). "Politics is long since dead. Only vultures remain, who divide up the body of ItaIy" (PC28, 2009). Other recurrent contrasts are between truth and deceit, but also between small and big: "We are like David and Goliath. We only have the web, the MeetUps, our enthusiasm and my meetings. They have all the rest. We are the last, the excluded, the derided. That's why we will succeed" (PC28, 2009).

Another cleavage that the M5S seized upon is generational. Grillo and other Five Star Movement leaders pointed out that Italy was run by "old men" with little ability to connect with the Italian youth. All of the political parties were dominated by a "gerontocracy". "These politicians don't know what they are talking about. They talk about the future. They are seventy years old and they talk about a future they will never see. We need young blood" (cited in Bordignon \& Ceccarini, 2014, p. 434). The movement's use of social media was part of the generational divide that Grillo harped on. Facebook, tweeter and other online social media were used not only to announce V-day events but also to stake out positions on a range of issues from the environment, European Union, youth unemployment, corruption issues, media monopolies, to immigration. The decentralized organizational style of the Five Star Movement is presented as something more in tune with a younger generation than the hierarchical traditional party structure.

While the Five Star Movement has attracted a younger base of support than the main political parties, the evidence indicates that the movement key demographic are Italian men in their mid-forties with a relatively high degree of interest in political and social issues. Along with this interest in politics is a corresponding disposition for social participation via Internet discussions; petitions initiatives, and signature and/or referendum proposals. For example, about $60 \%$ of respondents in a Demopolis survey of 1,206 have participated in local or environmental demonstrations, organized by M5S local groups. Overall, what emerges from the interviews is a propensity for new and alternative forms of mobilization and participation that contrast sharply with the more traditional mode of representation of Italian parties. ${ }^{5}$ In her study of M5S activists, De Rosa (2013, p. 129) confirms our profile,

Most of them were born in the South of Italy but live in the North-East. The vast majority of them are white-collar workers or self-employed professionals (in private firms or commerce) with a smaller group of university students...5SM activists would like to help Italy move forward but are blocked by a political class who are incapable of modernising themselves or the country, preferring to insist with conservative strategies. When questioned, the 5SM activists appear very radical as regards public administration, the media, the jobs market but much less so when it comes to support for a women's quota in parliament or the abolition of the legal value of a university degree. They refute the idea of leaderism and anti-politics as media simplification and prefer to think of themselves as anti-bad politics.

However, even with its focus on youth and technology, M5S is not really a youth movement. In keeping with the populist ideology of not representing groups based on ideology or class, Grillo makes a similar argument about generational divides. In fact, a central pillar in the Five Star Movement's political program is the protection and enhancement of pension funds for retirees.

\footnotetext{
${ }^{5}$ The survey was carried out by the Istituto Nazionale di Ricerche Demopolis from October 7-10, 2012 on a sample of 1,206 interviewees, representative of all Italian adult citizens, subdivided according to gender, age, and place of residence. http://www.demopolis.it
} 
The movement's blog has been used as a forum to criticize the media and others for not addressing the crisis faced by Italian retirees. The Northern League is the only other political party that has highlighted the plight of Italian pensioners. ${ }^{6}$

Although M5S defines itself as neither left nor right, it is viewed as having more of a center-left orientation on most socio-economic issues. In light of its "catch-all" characteristics and the contrasting policy positions it has taken a stance on, it is a difficult movement to pigeon hole. In fact, the base of support and mobilization of the M5S has varied over time depending on the type of topic and resentment it has sought to exploit. The data clearly indicates that the initial supporters of M5S were largely center-left. In 2010, "nearly half 48 percent of the M5S supporters positioned themselves as center-left" (Lanzone \& Scotto, 2014, p. 14). Two years later that number had dropped to 32 percent with those positioning themselves as center-right rising to 28 percent from 11 . The difficulty with classifying the M5S movement as center-left is illustrated with the rightest positions that Grillo has taken on the issue of immigration (Lanzone \& Tronconi, 2015).

Grillo, in particular, has staked out a position on immigration that is ideologically anchored to the right. For example, on the question of granting citizenship to the children of immigrants and overturning the punitive laws regarding illegal immigrants in Italy, Grillo's positioning on these divisive issues places him closer to the anti-immigrant Northern League. As Bordignon and Ceccarini noted (2013b, p. 433), "Grillo has declared his opposition to the granting of citizenship to the children of immigrants born in Italy, according to the principle of jus soli. Previously, he had strongly criticized the enlargement of the EU to include Romania, and the presence of Roma in Italy, evoking the sacredness of the borders of the fatherland". Grillo's anti-immigrant stance has provoked tension within the movement. Following the death of immigrants off the coast of Sicily in 2014 that led to some 5-Star movement elected senators calling for a reform of the Bossi-Fini law that criminalizes illegal immigrants (Woods, 2010). Grillo strongly rejected the call by M5S senators and threated to expulse them from the movement. He stated that "this amendment is an invitation to migrants from Africa and the Middle East to head for Italy.... How many immigrants can we accommodate if one Italian in eight does not have money?" (O'leary, 2013).

Another cleavage issue that Grillo has exploited is European integration. The European Union and integration had not been a salient issue in Italian politics. The left and the right as well as the general public had been overwhelmingly pro-European. The Northern League was the first political actor to disrupt the pro-European

6 See Grillo's blog posting "Bye, bye pensions". http://www.beppegrillo.it/en consensus. Although the party had initially been favorable to European integration and the creation of the euro, it changed its tune and became stridently antiEuropean. Until the emergence of the M5S movement, the Northern League had a kind of populist monopoly on anti-European rhetoric. Like with the immigration divide, Grillo seized on European integration cleavage that had been framed by a party on the right and redefined it in a new fashion. He called for Italy to leave the Euro and reject the austerity dictates of the European commission.

During the spring 2014 campaign for European parliament, Grillo stated, "We are Italy's Plan B", he told the BBC. "Brussels bureaucrats have distorted the dream of European democracy. Today, we are not at war with ISIS [Islamic State] or with Russia, we are at war with the European Central Bank!" (Bettiza, 2014). Much of Grillo anti-European appeal is tied to the economic crisis that Italy has confronted since 2009. Many in Italy viewed the fall of Berlusconi government in 2011 and the installation of a technocratic government led by Mario Monti as something that had been orchestrated by the European Union under the guidance of Germany and France. Grillo seized upon the austerity measures adopted by Monti's government as evidence that Italy had lost its freedom as a sovereign nation. In an interview, Grillo castigated the European Union for undermining the nation-state while proclaiming that he was a supporter of Europe:

On the contrary, I'm a staunch supporter of Europe, but I'd like to see the very concept of Europe revisited. When Monnet, along with many others, created Europe, he founded it on coal and steel-on tangible things. He was no technocrat. He used the post-war Marshall Plan manna. He knew that steel and coal were in German hands and that France would never manage these materials. He acted this way to manage concrete material. Now Europe is based on abstracts. Look at our finances. We have not only transferred our monetary sovereignty, but also our food supply. Do you realize that Italy has the best food in the world? Milk production centers are French. Supermarkets are French while ours are closing down one after the other. The free movement of workers has become the free movement of slaves. There are Georgians working on Romanian building sites. In Georgia there are Ukrainians and so on. It's the production of new slaves. ${ }^{7}$

A recurrent element that runs through Grillo's antiEuropean rhetoric is the question of representation. Like his criticism of the Italian "political caste", Grillo

\footnotetext{
7 Interviewed by Guiseppe Santoliquido, see We want to make honesty fashionable again (http://blog.lesoir.be/lesoirinenglish/2013/05/18/beppe-grillowe-want-to-make-honesty-fashionable-again).
} 
argues that the European Union is dominated by technocrats and self-interested politicians who care little about the "real people".

\section{The Organizational Form of the Five Star Movement: Personalized Representation}

Scholars generally view populist organizations as movements rather than parties. This categorization has developed because populism has historically been the carrier of anti-elitist (and also anti-system) ideological messages. Populist leaders often emerge initially from social and political movements and strongly reject what they claim is the non-representative nature of traditional political parties. In this respect, the Five Star Movement is no different. The Five Star Movement emerged as a protest movement and still views itself something different than a typical political party. It is a sort of non-traditional amorphous party that folds myriad of local and regional issues under the same tent.

Different from the "catch-all" parties of the past, the Five Star Movement does not have a large militant membership base. It relies on local "cleavage issue" entrepreneurs to mobilize supporters. Moreover, it is not a centralized bureaucratic party but more an amalgamation of local affiliates that are subservient to its charismatic leader. Local groups' activities-concentrated in the major cities-are characterized especially by square meetings and informative gazebos, but also by territorial petitions. However, it is only in online political discussions that M5S adherents are more active than supporters of other political movements in Italy. ${ }^{8}$ Thus, the web and Grillo's blog are clearly foci points that supporters of the movement use to engage in discussions and debates on a wide range of issues. As an indicator of its democratic credentials and authenticity, web-based referenda and votes are used regularly by the movement's leaders. These referenda are framed and dominated by Beppe Grillo to such an extent that claims to real democratic participation are dubious (Virgilio, Giannetti, Pedrazzani, \& Pinto, 2015).

Grillo is not only the founder and leader of the movement, but he is also its sole proprietor of its brand. The Five Star Movement is registered as a trademark on behalf of Beppe Grillo. Taggart (1995, p. 41) argues that such personalization of movements and parties is a structural characteristic of populism. He adds that "...the leadership is not a simple structural element. It is the mainstay of their messages and of their

8 Results from a web-based survey conducted between February 27 to March 132013 (method: Computer Assisted webinterviewing utilizing the diffusion technique known as survey monkey) of 628 individuals. Surveyed individuals responded to thirty-four structured questions that sought to assess their ideological orientation, level of civic participation, and online activism. party". In other words, charisma constitutes the cement of the entire project and is also the main mobilization vehicle to keep their supporters (McDonnell, 2015). The populist leader is pivotal to exploiting and polarizing popular resentment against the status quo (Ruggiero, 2012). In this respect, Grillo's personalized style of civic populism and some of his actions/demonstrations are reminiscent of the rise of Umberto Bossi. Grillo has recognized the parallel himself:

If I am resembled to Bossi, I not aggrieve myself, because Bossi was a street fighter with his undershirt. At that time, he screamed "Berlusconi you are a Mafioso". He said surprising things. Then, he became part of the system and the same system is addled. And so he entered in the Banks, in the milk quotas, in the dream of this Padania that it borders to Duck-burg. Bossi lost the sense of his thoughts. (Beppe Grillo, April 15, 2012) $^{9}$

In this message, Grillo emphasized again his opposition to the current political system and its political "caste", whose self-interested actions results in a betraying of the Italian people.

His personalization of M5S and his difficulty in allowing elected representatives of the movement much autonomy does not bode well for its future. However, its organizational flexibility and aggregation of disparate local and regional grievances appear to be sources of resilience. In recent regional elections, M5S lost votes but showed a remarkable presence in Italy's many small and medium sized towns in the seven regions in which the elections took place. Across the seven regions, it averaged about 17 percent of the vote.

\section{Conclusion}

The Five Star Movement is indicative of the kind of populist surge that has swept across Europe. Grillo has identified a broad range of local, regional and national issues over which there is a great degree of resentment and tethered them to the populist rhetoric of being a non-traditional political party that emerged as a true form of democratic representation. Like other populist movements, M5S sees itself as providing the real people with a true form of political representation that has been confiscated by elites. Bepe Grillo, as political entrepreneur, has stepped into the vacuum that Mair (2002) feared would be the consequence of the decline of traditional mediating role of European party system.

What sets Grillo's populist style apart is the use non-traditional media to mobilize supporters. In this sense, Grillo's movement is an example of a relatively new type of "web-based populism" (Corbetta, 2013, p.

9 The full Grillo's message is available at this link: http://www.youtube.com/ watch?v=pM9XTOR4MzU 
197). The use of the web has allowed M5S to combine old and new strategies of communication and mobilization. The use of the web and the actup and meetups in local centers in Italy lets the movement claim that it has finally brought to Italy a more direct form of democracy. In keeping with the logic of populism, it has done away with the traditional intermediaries of political parties and labor unions to allow the people to directly engage in politics via online discussion forums and public engagements. In general, all these aspects underline a heterogeneous base of M5S members and, more generally, voters characterized by the common resentment against political elites and traditional political parties (De Rosa, 2013).

The rise of the M5S is captured well by the three mechanisms specified in Pappas' model. Grillo's M5S movement seized on a pervasive resentment towards Italy's political class, it repackaged old cleavages or animated new ones and it effectively used non-traditional communication means to articulate an "us" versus "them" picture of political representation. The Five Star Movement was able to exploit to its advantage the strong resentment among many Italians towards their governing elite and to put together a heterogeneous base of support; however, this diversity of resentments makes it hard for the party to develop a coherent identity. After all, the old cleavages were able, for a long time, to engender some degree of loyalty among supporters who considered the party as the best vehicle for representation and participation in political life. It is not obvious that Grillo's volatile personality and "catch-all" strategy to aggregating local and regional grievances will suffice in transforming a potential majority into a real one.

\section{Acknowledgments}

We would like to thank the anonymous reviewers for their comments and suggestions that helped in improving the article.

\section{Conflict of Interests}

The authors declare no conflict of interests

\section{References}

Albertazzi, D., \& McDonnell, D. (Eds.). (2008). Twentyfirst century populism: The spectre of Western European democracy. London: Palgrave.

Albertazzi, D., \& Mueller, S. (2013). Populism and liberal democracy: Populists in government in Austria, Italy, Poland and Switzerland. Government and Opposition, 48, 343-371.

Bettiza, S. (2014, August 12). Italy's Grillo takes antieuro campaign to Brussels. BBC News.

Bobba, G., \& McDonnell, D. (2012). Beppe Grillo's unexpected rise makes him the Italian (non)politician of the year. Retrieved from

http://blogs.Ise.ac.uk/europpblog/2012/12/13/beppe -grillo-2012/

Bordignon, F., \& Ceccarini, L. (2012). Chi sale sull'autobus in MoVimento? Come cambia l'elettorato a 5 stelle. I/ Mulino, Bologna.

Bordignon, F., \& Ceccarini, L. (2013a). Ritratto politico dell'Italia di oggi. In I. Diamanti, F. Bordignon, \& L. Ceccarini, Un salto nel voto. Ritratto politico dell'Italia di oggi. Roma-Bari: Laterza.

Bordignon, F., \& Ceccarini, L. (2013b). Five stars and a cricket. Beppe Grillo shakes Italian politics. South European Society and Politics, 18, 427-449.

Bull, M. J. (2012). The Italian transition that never was. Modern Italy, 17(1), 103-118.

Bull, M. J., \& Rhodes, M. (2009). Introduction-Italy: A contested polity. West European Politics, 30(4), 1-13.

Casaleggio, G., \& Grillo, B. (2011). Siamo in guerra per una nuova politica. La rete contro i partiti. Milan: Chiarelettere.

Corbetta, P. (2013). Un web-populismo dal destino incerto. In P. Corbetta \& E. Gualmini (Eds.), II partito di Grillo (pp. 197-214). Bologna: II Mulino. De Rosa, R. (2013). The five star movement in the Italian political scenario. A case for cybercratic centralism? JeDem, 5(2), 128-140.

Diamanti, I. (2013). II Paese delle minoranze incommunicanti. In I. Diamanti, F. Bordignon, \& L. Ceccarini, Un salto nel voto. Ritratto politico dell'Italia di oggi. Roma-Bari: Laterza.

Gould, A. C. (1999). Conflicting imperatives and concept formation. The Review of Politics, 61(3), 439-463.

Ignazi, P. (1996). The crisis of parties and the rise of new political parties. Party Politics, 2, 549-566.

Jagers, J., \& Walgrave, S. (2007). Populism as political communication style: An empirical study of political parties' discourse in Belgium. European Journal of Political Research, 46, 319-345.

Kriesi, H. (2014). The populist challenge. West European Politics, 37, 361-378.

Kriesi, H., \& Pappas, T. S. (2015). Chapter 18: Populism and crisis: A fuzzy relationship. In $\mathrm{H}$. Kriesi \& T. S. Pappas (Eds.), European populism in the shadow of the Great Recession. Colchester: ECPR.

Laclau, E. (1977). Politics and ideology in Marxist theory. London: New Left Books.

Lanzone, M. E. (2014). The "post-modernist" populism in Italy: The case of the Five Star Movement. In D. Woods \& B. Wejnert (Eds.), The many faces of populism: Current perspectives. London: Emerald Press.

Lanzone M. E., \& Scotto A. (2014). Iscritti e primarie: II movimento 5 stelle tra attivisti del web e "parlamentarie". Paper presented at the XXVIII Convegno Annuale Sisp 2014, University of Perugia, Italy. Retrieved from http://www.sisp.it/files/papers/2014/ maria-elisabetta-lanzone-angelo-scotto-1836.pdf

Lanzone, M. E., \& Tronconi, F. (2015). Between blog, 
social networks and territory: Activists and grassroots organisation. In F. Tronconi (Ed.), Beppe Grillo's Five Star Movement. Organization, Communication and Ideology. Farnham: Ashgate.

Lazar, M. (2013). Testing Italian democracy. Contemporary European Politics, 11, 317-336.

Mair, P. (2002). Populist democracy vs party democracy. In Y. Meny \& Y. Surel (Eds.), Democracies and the populist challenge (pp. 81-98). Basingstoke: Palgrave.

Mannheimer, R. (1991). La crisi del consenso per i partiti tradizionali. In R. Biorcio, I. Diamanti, R. Mannheimer, \& P. Natale (Eds.), La Lega Lombarda (pp. 13-33). Milan: Feltrinelli.

Mannheimer, R. (1993). L'elettorato della Lega Nord. Polis, 7, 253-274.

McDonnell, D. (2015). Populist leaders and coterie charisma. Political Studies. Doi: 10.1111/1467-9248.12195

Meny, Y., \& Surel, Y. (2002). The constitutive ambiguity of populism. In Y. Meny \& Y. Surel (Eds.), Democracies and the populist challenge. Basingstoke: Palgrave.

Mosca, L. (2014). The Five Star Movement: Exception or vanguard in Europe? International Spectator, 49(1), 36-52.

Mudde, C. (2004). The populist zeitgeist. Government and Opposition, 39, 541-563.

Newell, J. L. (2009). The man who never was? The Italian transition and 2008 election. Journal of Modern Italian Studies, 14(4), 395-412.

O'leary, N. (2013, October 11). Immigration dispute shows fault lines in Italy's M5S. Reuters.

Pappas, T. (2012). Populism emergent: A framework for analyzing its contexts, mechanics and outcomes (EU Working Papers No. RSCAS 2012/01). Florence, Italy: European Union Institute.

Rizzo, S., \& Stella, A. (2007). La casta. Cosi i politici italiani sono diventati intoccabili. Milan: Rizzoli.

Ruggiero, C. (2012). Forecasting in the politics of spectacle, from Berlusconi to Grillo: The narrative of im- polite politics. Bulletin of Italian Politics, 4, 305-322

Santoro G. (2012). Un Grillo Qualunque. II Movimento 5 stelle e il populismo digitale nella crisi dei partiti italiani. Roma: Castelvecchi Editore.

Shin, M. E., \& Agnew, J. A. (2008). Berlusconi's Italy. Mapping contemporary Italian politics. Philadelphia, PA: Temple University Press.

Taggart, P. (1995). New populist parties in Western Europe. West European Politics, 1, 34-51.

Taggart, P. (2002). Populism and the pathology of representative politics. In Y. Meny \& Y. Surel (Eds.), Democracies and the populist challenge (pp. 62-79). Basingstoke: Palgrave.

Taggart, P. (2004). Populism and representative politics in contemporary Europe. Journal of Political Ideologies, 9(3), 269-288.

Tarchi, M. (2008). Italy: A country of many populisms. In D. Albertazzi \& D. McDonnell (Eds.), Twenty-first century populism: The spectre of Western European democracy (pp. 84-99). Basingstoke: Palgrave.

Virgilio, D. A., Giannetti, D., Pedrazzani, A., \& Pinto, L. (2015). The Five Stars Movement in the Italian political scenario. A case for cybercratic centralism? Government and Opposition, 50, 65-89.

Woods, D. (1992). The centre no longer holds: The rise of regional leagues in Italian politics. West European Politics, 15, 56-76.

Woods, D. (1995). The crisis of center-periphery integration in Italy and the rise of regional populism: The Lombard League. Comparative Politics, 27(2), 187-203.

Woods, D. (2010). A critical analysis of the Northern League's ideographical profiling. Journal of Political Ideologies, 15, 189-219.

Woods, D. (2014). The many faces of populism in Italy: The Northern League and Berlusconism. In D. Woods \& B. Wejnert (Eds.), The many faces of populism: Current Perspectives. London: Emerald Press.

\section{About the Authors}

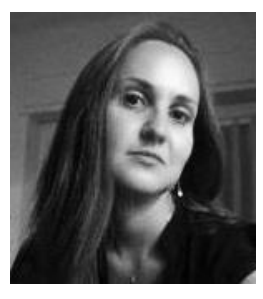

\section{Dr. Liza Lanzone}

Maria Elisabetta Lanzone obtained a PhD in political science from the University of Pavia. In 2015 she spent a short period as a visiting scholar at the "Laboratoire ERMES", University of Nice SophiaAntipolis, where she is currently Chercheur Associé. Her main research areas are Italian political parties, political participation inside populist organization and candidate selection procedures. She is the author of II MoVimento cinque stelle. II "popolo" di Grillo dal web al parlamento (2015) and "The post-modern populism in Italy: the case of the Five Star Movement", in D. Woods and B. Wejnert (2014).

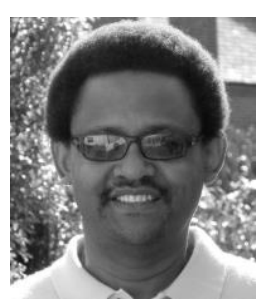

\section{Dr. Dwayne Woods}

Dwayne Woods is an Associate Professor of Political Science at Purdue University in West Lafayette, IN. His areas of specialization are comparative politics, methodology, and political economy. His most recent publication: "The many faces of populism in Italy: The Northern League and Berlusconism" in D. Woods \& B. Wejnert (Eds.), The many faces of populism: Current Perspectives. London: Emerald Press. 